\title{
Changing the Land Scape in Adjuvant Setting in RCC
}

\author{
Mohamed Emam* \\ Cairo University, Egypt \\ Submission: November 28, 2017; Published: December 18, 2017 \\ "Correspondence Address: Mohamed Emam, Cairo University, Egypt, Email: dr_moh_emam@yahoo.com
}

\section{Editorial}

Renal cell carcinoma is the most common type of kidney cancer in adults. It accounts for approximately $3 \%$ of adult malignancies and $90-95 \%$ of neoplasms arise from the kidney [1]. Surgical resection remains the only known curative treatment for localized renal cell carcinoma, and it is also used to improve outcome or for palliation in metastatic disease. Our need for adjuvant therapy in RCC comes from that $45 \%$ of cases are localized and $25 \%$ of cases are locally advanced. Also, $33 \%$ of patients treated for localized disease will develop metastases commonly to lung, bone, liver and brain [2]. A lot of clinical trials in adjuvant setting were done and showed negative results but some of them showed detrimental effect. Recently there are two ongoing trials evaluating the outcome of sunitinib in adjuvant setting with contradictory results

The Assure trial, Double-blind, randomized phase III trial that: Involved 1943 patients with completely resected locally advanced RCC of either clear or non-clear cell histology who were stratified as intermediate to high or very high risk on the basis of University of California, Los Angeles, international staging criteria [3]. Patients were assigned to either sunitinib daily for 4 of 6 weeks for nine cycles for 1 year; sorafenib, twice daily for nine cycles for 1 year; or placebo for 1 year [3]. Overall survival rates ranged between $77 \%$ and $81 \%$ in all treatment groups, "so again, essentially no difference on this initial assessment [3]. This is the first and largest trial reporting on efficacy with VEGF inhibitors as adjuvant therapy for patients with locally advanced kidney cancer who were at high risk for recurrence," at 5 years, median DFS rates were not different between the three groups, at 5.6 years for sorafenib and sunitinib and 5.7 years for placebo.

In contrast to S-TRAC trial a multicenter, international, double-blind, placebo-controlled trial, in 615 patients with high risk for recurrent RCC following nephrectomy. Patients were randomized 1:1 to receive either $50 \mathrm{mg}$ sunitinib malate once daily, 4 weeks on treatment followed by 2 weeks off, or placebo. Median disease-free survival (DFS) for patients taking sunitinib malate was 6.8 years $(95 \%$ CI: 5.8, not reached) compared with 5.6 years $(95 \% \mathrm{CI}: 3.8,6.6)$ for patients receiving placebo (HR=0.76; 95\% CI: 0.59, 0.98; $\mathrm{p}=0.03$ ). At the time of
DFS analysis, overall survival data were not mature. The most common adverse reactions $(\geq 25 \%)$ to sunitinib malate are fatigue/asthenia, diarrhoea, mucositis/stomatitis, nausea, decreased appetite/anorexia, vomiting, abdominal pain, handfoot syndrome, hypertension, bleeding events, dysgeusia/ altered taste, dyspepsia, and thrombocytopenia [4].

The period of follow-up in S-TRAC trial (median, 5.4 years) was similar to that in the ASSURE trial (median, 5.8 years). However, since the life expectancy after nephrectomy in this population of patients is nearly $40 \%$ at 10 years further study is needed to confirm whether the effect of adjuvant sunitinib treatment is maintained in the long term [4]. Distinct patient populations, dose regimens, and trial methods are likely to be responsible for the different outcomes in the two trials. For example, the ASSURE trial included many patients with early (stage 1) tumors (9\%) and patients with non-clear-cell histologic result (21\%), whereas S-TRAC trial was designed to include only patients with late-stage (loco regional), clear-cell renal-cell carcinoma [4]

In the ASSURE trial, the starting dose of sunitinib was changed midtrial, from $50 \mathrm{mg}$ to $37.5 \mathrm{mg}$, with subgroup analysis showing a trend toward a shorter duration of disease-free survival for those who initiated treatment at $37.5 \mathrm{mg}$; furthermore, dose reductions to $25 \mathrm{mg}$ were allowed. In contrast, sunitinib was administered at $50 \mathrm{mg}$ in S-TRAC trial, with dose reduction allowed to $37.5 \mathrm{mg}$ per day but not $25 \mathrm{mg}$ per day [4]. So, on 16 November 2017, the US Food and Drug Administration (FDA) approved sunitinib malate (Sutent, Pfizer Inc.) for the adjuvant treatment of adult patients at high risk of recurrent renal cell carcinoma (RCC) following nephrectomy.

\section{References}

1. Cancer Facts \& Figures (2017) American Cancer Society, USA.

2. Flanigan RC, Campbell SC, Clark JI, Picken MM (2003) Metastatic renal cell carcinoma. Curr Treat Options Oncol 4(5): 385-390.

3. Haas NB (2015) ASCO, Abstract 4508.

4. Alain Ravaud, Robert J Motzer, Hardev S Pandha, Daniel J George, Allan J Pantuck (2016) Adjuvant Sunitinib in High-Risk Renal-Cell Carcinoma after Nephrectomy. N Engl J Med 375: 2246-2254. 
This work is licensed under Creative Commons Attribution 4.0 License DOI: $10.19080 /$ CTOIJ.2017.08.555739
Your next submission with Juniper Publishers will reach you the below assets

- Quality Editorial service

- Swift Peer Review

- Reprints availability

- E-prints Service

- Manuscript Podcast for convenient understanding

- Global attainment for your research

- Manuscript accessibility in different formats ( Pdf, E-pub, Full Text, Audio)

- Unceasing customer service

Track the below URL for one-step submission https://juniperpublishers.com/online-submission.php 